http://dx.doi.org/10.12775/szhf.2016.027

\author{
MiroseaW ŻelazNy \\ Uniwersytet MikoŁaja Kopernika, Toruń, Polska \\ ZELAZNY@UMK.PL
}

\title{
Stosunek Salomona Majmona do filozofii Kanta \\ (w świetle korespondencji i nowo odkrytego manuskryptu Rozmowa pomiędzy Kantem i jednym z jego stuchaczy)
}

Biografia Salomona Majmona jest sama w sobie niezwykle interesująca, niezależnie od jego dorobku pisarskiego. Urodził się w 1753 roku, jak sam stwierdził, jako polski żyd w lasach litewskich. W bardzo wczesnym wieku został mężem i ojcem. Z rodzinnego środowiska wyniósł tylko znajomość języków jidysz, hebrajskiego i polskiego, jeśli zaś chodzi o wykształcenie, dysponował wiedzą talmudyczną. W wieku dwudziestu kilku lat porzucił rodzinę i udał się do Niemiec w celu zdobycia wykształcenia. Krótko przebywał w Królewcu, gdzie nie zetknął się jednak z Kantem, potem zaś przeniósł się do Berlina. Utrzymywał się dzięki pomocy lokalnych środowisk żydowskich, udzielał też jakichś korepetycji. Nigdy nie podjął systematycznych studiów i był zupełnym samoukiem. Mimo to w roku 1790 wydjął rozprawę Versuch über Transcendentalphilosophie, w której deklarował, że jest kontynuatorem myśli Kanta. W istocie okazał się jej przeciwnikiem i to w kwestiach zupełnie podstawowych. 
W kontaktach międzyludzkich był człowiekiem niebywale sprytnym. Szybko zawarł bliskie kontakty z Mosessem Mendelssohnem, przede wszystkim zaś z bliskim przyjacielem Kanta, Marcusem Herzem. Za jego pośrednictwem wysłał filozofowi wspomnianą pracę z prośbą o ocenę, później napisał do autora Krytyki czystego rozumu szereg listów, na które ten już nie odpowiedział.

Listy te wyróżniają się na tle pozostałej korespondencji, którą Kant otrzymywał, najdelikatniej można byłoby je określić jako „zuchwałe”. W większości z nich znajdujemy na początku zachwyt nad filozofią Kantowską. Potem pojawia się jednak "ale” i Majmon postuluje wprowadzenie do tej filozofii drobnych poprawek. Nie chodzi mu jednak o poprawki drobne, lecz zasadnicze, takie, które całkowicie odwracałyby sens nauki Kanta, zwracając ją w stronę idealizmu.

$\mathrm{Na}$ listy te Kant nie odpowiadał, z jednym wyjątkiem. Ponieważ Majmon wkupił się w łaski Herza, raz udzielił mu krótkiej odpowiedzi. Odpowiedź ta zawarta jest w tomie listów Akademie-Ausgabe (dalej Ak.) pod numerem [361] ${ }^{1}$. Późniejszy tłumacz na język polski Autobiografii Majmona Bella Szwarcman-Czarnota przetłumaczył ten liścik następująco:

Pańskiemu szlachetnemu pragnieniu usiłowałem dogodzić w tej mierze, w jakiej jestem sprawny, a jeżeli stało się to nie w formie oceny całkowitego Pańskiego traktatu, to przyczynę tego zaniechania pozna Sz. Pan z mojego listu do Pana H. Niewątpliwie nie jest nią lekceważenie, którego nie mogę mieć w sobie dla żadnej w ogóle poważnej dążności w sferze rozumnych i obchodzących ludzkość dociekań, a tym bardziej dla takiej pracy, jak Pańska, która zdradza w samej rzeczy niezwykły talent do nauk głębokich².

Właściwą odpowiedź w kwestii rozprawy Majmona zawarł natomiast Kant w liście do Herza [Ak. 362]. Na początku żalił się, że Herz obarcza go takimi obowiązkami, jak czytanie czyichś rękopisów, potem dyplomatycznie zamieścił liczne komplementy pod adresem Majmona, chwaląc jego talent, pilność itp., wreszcie przeprowadził druzgocącą krytykę przesłanej mu pracy, podkreślając zwłaszcza, że jest ona skierowana przeciwko jego własnej filozofii krytycznej.

${ }^{1}$ Wszystkie listy opublikowane w niniejszym tomie: Immanuel Kant i Salomon Majmon, Korespondencja (przełożyli i opracowali Marta Szymańska-Lewoszewska i Mirosław Żelazny), s. 29 i nast.

${ }^{2}$ Tłumaczenie to jest moim zdaniem odrobinę przesłodzone. Por. [Ak. 361]. 
Interesujące jest, że po tym liście z 26 maja 1789 korespondencja między Herzem a Kantem, wcześniej obfita i pełna zwierzeń osobistych, nagle ustała. Potem obaj panowie wymieniali tylko nieliczne, bardzo oficjalne listy.

Majmon najwyraźniej nie zdawał sobie do końca sprawy z takiego stanowiska Kanta w stosunku do własnej osoby. Ale ta kwestia, podobnie jak sprawa nagłego zawieszenia korespondencji między Herzem a Kantem, wymaga jeszcze wyjaśnienia. Faktem jest natomiast to, że sam Majmon zachowywał się tak, jak gdyby nic nie wiedział o tym, jak Kant go ocenił. Przywołanego tu, skierowanego do niego krótkiego listu używał jeszcze potem wielokrotnie, na przykład starając się o wydanie swojej rozprawy, o którą toczył się spór. Ukazała się ona w 1790 roku. Również w swej Autobiografii, Majmon pisał, że autor Krytyki czystego rozumu miał o jego filozofii jak najlepsze zdanie.

Wysyłał do Kanta jeszcze kilka listów utrzymanych w opisanym powyżej tonie, na które nie otrzymał żadnej odpowiedzi, mimo to pisał dalej, a Kant dalej nie odpowiadał. Najwyraźniej bolało to Majmona, gdyż postanowił pewnego razu odpowiedzi te napisać sam. Zostały one zamieszczone w dialogu Gespräch zwischen Kant und einem seiner Zuhörer, który zachował się w Bibliotece Czartoryskich w Krakowie. Znajduje się on pod jedną sygnaturą $\mathrm{z}$ rękopisem Gedanken über bürgerliche Verbesserung der Hebraiker, powstałym po ostatnim rozbiorze Polski, najprawdopodobniej około $1796 \mathrm{roku}^{3}$.

We wspomnianym dialogu Majmon zdaje się rekompensować sobie wszystkie doznane od Kanta „krzywdy”. Rozmówcą wielkiego filozofa jest słuchacz N., głoszący właśnie poglądy Majmona. Jest on adwersarzem stanowczym i natarczywym. Jego pytania przypominają przesłuchanie. Kant grzecznie odpowiada, ale nie jest w stanie mu dorównać. Gubi się, popada w sprzeczności, akceptuje takie tezy partnera, które pozostają w wyraźnej sprzeczności z literą filozofii krytycznej.

Opisana powyżej historia mogłaby mieć charakter wyłącznie interesującej anegdoty, jednej z wielu związanych z życiem i filozofią autora Krytyki czystego rozumu. W niniejszym artykule chciałbym jednak postawić hipotezę interpretacyjną, że być może dotyczy ona dość istotnych wydarzeń z historii filozofii. Na wstępie postawmy tu pytanie: jakie wątki filozofii Kantowskiej sprowokowały jej interpretację, a właściwie, jak twierdzi Kant, dezinterpretację dokonaną przez Majmona?

Podstawowe założenie filozofii Kanta brzmi, że proces poznania wyrasta z dwu autonomicznych źródeł, z receptywności i samorzutności. Receptyw-

\footnotetext{
${ }^{3}$ Rkps Bibl. Czart. nr 00174 i 00175.
} 
ność to zdolność doświadczeń zmysłowych. Samorzutność to zdolność myślenia w kategoriach i pojęciach. Zdolność czystego myślenia w kategoriach określa Kant mianem intelektu. Intelekt nie może być intuitywny, to znaczy nie może on sam z siebie oglądać. Oglądu dokonuje on za pośrednictwem zmysłów. I tu pojawia się pytanie: w jaki sposób kategorie intelektu, należące do autonomicznej sfery poznania, mogą w sposób determinujący określać prawa zachodzące wśród przedmiotów zmysłów? Innymi słowy: jak intelekt może wyznaczać związek przyczynowo-skutkowy dla świata zmysłów? Hume zaprzeczył takiej możliwości, Kant ją przywrócił.

Gdy jednak pytamy o powyższą możliwość, pojawia się natychmiast pytanie o to, czym jest świat zmysłów. Składają się na niego dwie sfery: zmysł zewnętrzny oraz zmysł wewnętrzny. Pierwszą tworzą fenomeny, które oto odczuwam, na przykład to oto pióro, którym piszę i które czuję teraz. Na drugą przedstawienia i wyobrażenia, które wytwarza mój zmysł wewnętrzny. Przedmioty zmysłu wewnętrznego to przede wszystkim wspomnienia czegoś, co kiedyś odczuwaliśmy w zmyśle zewnętrznym, ale „teraz” możemy je sobie tylko przypomnieć. W języku potocznym powiemy, że fenomenem jest coś, co postrzegamy jako będące teraz, a przedmioty zmysłu wewnętrznego to coś, co nie jest tu, bo już było. A jeśli jest, to tylko siłą mojej pamięci i wyobraźni.

Tu powraca klasyczny problem Augustyna: czym jest teraz? Jeśli uznamy je za dowolny odcinek czasowy, trwający na przykład sekundę lub jeszcze mniej, to odcinek taki natychmiast będzie musiał mieć swą własną przeszłość i tajemnicze „teraz”. Jeśli zaś chcielibyśmy użyć tu kategorii punktu, to okaże się, że żadna punktowość nie może być przedmiotem doświadczenia zmysłowego. Jak więc ustalić granicę pomiędzy zmysłem zewnętrznym i wewnętrznym? O ile mi wiadomo, ten niezwykle ważny problem Kant podejmuje tylko raz, w niewielkiej notatce $O$ zmyśle wewnętrznym, odnalezionej w Petersburgu w latach 80. ubiegłego wieku.

„Cała trudność polega właściwie na tym, że nie sposób pojąć, jak możliwy jest zmysł zewnętrzny (który idealista musi odrzucić), gdyż to, co zewnętrzne trzeba przedstawić sobie zanim zostanie w nim ustanowiony jakiś obiekt"4.

Zwróćmy uwagę na to, co jest napisane w nawiasie: „idealista musi [wewnętrzny zmysł] odrzucić”. I w tym sensie idealiści go odrzucą: uczyni to Fichte, Schelling i Hegel. Być może pierwszym z nich był Majmon.

${ }^{4}$ I. Kant, O zmyśle wewnętrznym, [w:] tenże, O postępach metafizyki, przeł. A. Banaszkiewicz, Gdańsk 2007. 
Kant zdaje sobie sprawę, że nie istnieje możliwość wyznaczenia granicy pomiędzy zmysłem zewnętrznym i wewnętrznym, bo w tym celu należałoby odpowiedzieć na pytanie, czym jest granica pomiędzy „było” a „jest teraz”. Pewnego modelowego rozwiązania problemu tej granicy dokonał dopiero Husserl, wprowadzając pojęcie „plamy trwania”. Czy jego rozwiązanie zadowoliłoby Kanta? Chyba nie. Plama trwania, powiedziałby ten ostatni, jest tylko hipotetyczną demonstracją intelektu i wyobraźni, która dla doświadczenia zmysłu zewnętrznego wciąż pozostaje tworem nieosiągalnym.

Ale Kant nie sięga tak daleko. Powiada po prostu: nie wiem, jak określić granicę między zmysłem zewnętrznym i wewnętrznym. Można byłoby dokonać tego logicznie, tak jak idealiści, stwierdzając, że zmysł zewnętrzny tak naprawdę wcale nie istnieje i dowodząc takiego stwierdzenia logicznie. Dla Kanta, ów dowód byłby jednak tylko pozorem logicznym, takim samym jak paradoks Zenona, głoszący, że Achilles nie dogoni żółwia. Paradoks ten ostatecznie rozwiązano chyba dopiero w XIX wieku. Nie zmienia to jednak faktu, że logika, z której on rzekomo wynikał, nigdy nikomu nie mogła przemówić do wyobraźni. Każdy człowiek, nawet pozbawiony jakiegokolwiek doświadczenia, wie przecież, że ten, kto biegnie szybko, dogoni tego, kto biegnie wolno. Na analogicznej zasadzie mój zmysł rejestruje pióro piszące tu i teraz jako fenomen zmysłu zewnętrznego, pióro zaś, które przekreśliło słowo w wierszu powyżej, jako wyobrażenie zmysłu wewnętrznego. Wywody na temat, że różnica pomiędzy zmysłem wewnętrznym i zewnętrznym są pozorne, dawałyby nam pozór logiczny podobny do tych, które stworzył Parmenides i z których miało wynikać, że nie istnieje ruch. Bywają jednak filozofowie, którzy na takim pozorze chcieliby budować całe swe systemy, czyli wyprowadzać z samej tylko logiki konieczność istnienia lub nieistnienia przedmiotów doświadczalnych. To idealiści.

Niemożliwość stworzenia jednolitej teorii poznania zmysłowego, rekonstruującej wszystkie relacje pomiędzy zmysłem zewnętrznym i wewnętrznym, nie jest więc, zdaniem Kanta, możliwa już z tego powodu, że nie jest możliwe doświadczenie absolutnej empirycznej dedukcji żadnego przedmiotu. A ponieważ chodzi tu o sferę receptywności, a nie spontaniczności, owa tajemnicza granica pomiędzy zmysłem zewnętrznym a zmysłem wewnętrznym musiałaby być doświadczana, a nie wydedukowana.

Struktura czystego rozumu jest w stanie dać nam transcendentalną jedność procesu poznawczego, ale ta transcendentalna jedność nie może zastąpić jego poszukiwanej jedności empirycznej. Gdy idzie o tę ostatnią, to trudno nawet sobie wyobrazić, na czym miałaby ona polegać. 
Transcendentalnie ujęta jedność procesu poznawczego wygląda zaś następująco. We wspomnianym liście do Herza [Ak. 362], odrzucając poglądy Majmona, Kant przypomniał, jak jest możliwe, że światy zmysłu zewnętrznego i wewnętrznego, mimo że tak są od siebie różne i że nie da się pomiędzy nimi wytyczyć granicy, stanowią jednak jedność. Otóż jedność ta ma charakter formalny, a nie materialny. Wynika ona stąd, że podstawę obu światów stanowi przestrzeń jako czysta forma oglądu (czas jako idea następowania faktów po sobie charakteryzowałaby tylko zmysł wewnętrzny). Połączenia obu form zmysłowości, zmysłu zewnętrznego i wewnętrznego, receptywność dokonuje więc swymi własnymi siłami. Nie potrzebuje w tym celu jedności uzyskiwanej dopiero przez kategorie. Tak pojmowaną jedność zmysłowości nazywa Kant jednością przez aprehensję ${ }^{5}$.

Jak możemy się dowiedzieć z korespondencji skierowanej do Kanta, wielu pozostających $\mathrm{z}$ nim $\mathrm{w}$ kontakcie filozofów miało kłopoty ze zrozumieniem, czym w systemie Krytyki czystego rozumu jest przestrzeń jako czysta forma oglądu. Pytano, czy nie jest ona po prostu jednym z przedstawień, a nawet, czy nie jest pojęciem, a nie żadną formą zmysłowości. Jak zobaczymy za chwilę, wątpliwości takie zgłosi również Majmon.

Na razie dokończmy przypomnienie struktury systemu jedności poznania poprzez system aprehensji. Kolejne pytanie, które się w tym kontekście pojawia, brzmi: w jaki sposób prawa wiedzy w kategoriach mogą być stosowane do doświadczeń zmysłowych, skoro intelekt nie jest intuitywny, a zatem wiedzy o żadnym przedmiocie nie może uchwycić jako wiedzy absolutnej? Tu Kant wprowadza kategorię determinującej władzy sądzenia. Jest to właśnie zdolność trafnego odnoszenia wiedzy teoretycznej do określonego typu doświadczenia. Władza sądzenia jest władzą rozumu, niezależną od prawd intelektu i prawd zmysłowych. Jest zdolnością trafnego odnoszenia jednych do drugich. Prawdziwość dokonywanych przez nią wyborów zweryfikowana zostaje dopiero praktycznie, właśnie przez fakt, że czysta wiedza w kategoriach zgadza się z wynikami doświadczenia.

${ }^{5}$ Por. tenże, Krytyka czystego rozumu, przeł. M. Żelazny, [w:] tenże, Dzieła zebrane, t. 2, s. 190, przyp. tłum. Majmon w swym Philosophisches Wörterbuch (Berlin 1791, s. 14) pojmuje pojęcie aprehensji zupełnie inaczej niż Kant. Uważa je za synonimiczne z pojęciem skojarzenia (Association). Ale nie jest to dobra interpretacja. Skojarzenia to aktywność umysłu starająca się podporządkować dwa spostrzeżenia pod jedną zasadę na podstawie ich podobnych cech. W przypadku aprehensji, odnoszącej się do czystej formy przestrzeni owo podporządkowanie dokonuje się nie pod wpływem podobieństwa, ale identyczności bądź różnicy cech przysługujących czystym figurom geometrycznym. 
Ani dla Majmona, ani dla tworzącego wkrótce po nim Fichtego, protoplastów postkantowskiego idealizmu, pojęcie determinującej władzy sądzenia nie odgrywało istotnej roli. Majmon nie interesował się też pojęciem aprehensji, czyli jedności poznania czysto zmysłowego (wewnętrznego i zewnętrznego) przez czystą formę oglądu. Z trzech faz uzyskiwania transcendentalnej jedności systemu apercepcji - poprzez czystą formę oglądu, determinującą władzę sądzenia i intelekt - za obowiązującą uznawał tylko tę ostatnią. Podobnie uczynił Fichte.

Dla Kanta takie rozwiązanie byłoby nie do przyjęcia. Wypowiedział się na ten temat jasno. Po raz pierwszy we wspomnianym liście do Herza z 26 maja 1789 [Ak. 362], gdzie krytykował stanowisko Majmona, a po raz drugi w sławnym otwartym liście z 7 sierpnia 1799, skierowanym przeciwko Fichtemu. Stwierdza tam, że osiągnięcie pełnej jedności systemu apercepcji wyłącznie na mocy wiedzy pojęciowej byłoby niedorzecznością ${ }^{6}$. Gdyby intelekt miał tego dokonać, musiałby być nie dyskursywny, ale intuitywny. To by oznaczało, że mógłby on wyprowadzać istnienie przedmiotów z samej logiki, bez udziału zmysłów. Przedmioty doświadczenia nie byłyby wówczas niczym innym, aniżeli formą pojęć.

Takie idealistyczne stanowisko określił Kant potem w swych listach do Fichtego mianem scholastyki, odradzając adresatowi podobny sposób filozofowania. Fichte odpowiada na to, że momentu scholastycznego nie spuści $\mathrm{z} \mathrm{oka}^{7}$. Nie wiadomo, czy deklarację tę należy traktować poważnie, czy była ona formą przekory. Tak czy inaczej, patrząc z pozycji Kanta, Fichte poszedł drogą scholastyki, bo tak można byłoby nazwać stanowisko idealistyczne, od którego sam autor Krytyki czystego rozumu zdecydowanie się odżegnywał.

Zdaniem Kanta stanowisko to w pierwszym kroku oznaczało odwołanie się do pozoru logicznego, znoszącego różnicę pomiędzy fenomenami zmysłu zewnętrznego a przedstawieniami zmysłu wewnętrznego. W drugim kroku, również w wyniku pozoru logicznego, dochodziło do zniesienia różnicy pomiędzy przedmiotem zmysłowym w ogóle a pojęciem, czyli pomiędzy receptywnością i samorzutnością.

Tą scholastyczną drogą podążył Majmon. W liście z 7 kwietnia 1789 [Ak. 352] zadał Kantowi cztery pytania, które wskazują, że treść Krytyki czystego rozumu znał bardzo pobieżnie:

${ }^{6}$ Tłum. polskie Historia filozofii, pod red. S. Aleksandrowa, Warszawa 1972, t. 3, s. 161-162.

${ }^{7}$ Tamże, por. [Ak. 794]. 
1. Różnicy, jaką odnajduje Pan pomiędzy zdaniami analitycznymi i syntetycznymi oraz realność tych ostatnich.

2. Pytanie Quid Juris? Pytanie ze względu na swą wagę godne Kanta oraz wymiar, który sam mu Pan nadał, pytając: w jaki sposób można $\mathrm{z}$ całą pewnością aplikować coś a priori na coś a posteriori? Odpowiedź albo dedukcja, którą dał nam Pan w swych pismach, taką jak dać mógł tylko Kant, jest w pełni zadowalająca. Jeśli jednak chcielibyśmy to pytanie pociągnąć dalej: w jaki sposób można pojęcie a priori rozciągnąć na ogląd i to ogląd a priori? Takowe pytanie naturalnie oczekuje na mistrza, który mógłby na nie odpowiedzieć.

3. Nowy, zauważony rodzaj idei, który nazywam ideami intelektualnymi i które również wskazują na totalitarność materialną, tak jak wskazane przez Pana idee rozumowe wskazują na totalność formalną, sądzę, że otworzyłem tu nową perspektywę, gdy idzie o odpowiedź na pytanie Quid Juris?

4. Pytanie Quid facti? - wydaje się, że ledwie je Pan poruszył; a z powodu wątpliwości Hume’a zdaje mi się być ważne, by na nie zadowalająco odpowiedzieć.

Stawiając pytanie drugie, Majmon zupełnie pomija rolę, jaką Kant, gdy chodzi o związek szczególności doświadczeń z ogólnością wiedzy pojęciowej, przypisuje determinującej władzy sądzenia. W systemie Krytyki czystego rozumu żydowski filozof widzi lukę polegającą na tym, że Kant rzekomo nie odpowiedział na pytanie, w jaki sposób wiedzę a priori można byłoby odnieść do poznania empirycznego tak, by uzyskać ich pełną zgodność. Pytanie to, stwierdza, oczekuje na mistrza.

Gdyby Kant chciał być przekorny, zgodziłby się z nim i odpowiedziałby, że takim mistrzem może być tylko Bóg, bo tylko o nim da się pomyśleć, że dysponuje intelektem intuitywnym. Aby być skutecznym scholastykiem, stwierdza Kant, trzeba być Bogiem. Majmon, a po nim Fichte uznają jednak, że z zadania tego może się wywiązać człowiek.

Poszukując takiej jedności ludzkiego świata przez intuitywny, lecz dostępny nam intelekt, odwołuje się do tajemniczego przedmiotu, który pod ten intuitywny intelekt faktycznie ma podlegać i któremu nadaje nazwę idea intelektualna. Idee intelektualne wskazują na „...totalność materialną, tak jak wskazane przez Pana idee rozumowe wskazują na totalność formalną. Sądzę, że otworzyłem tu nową perspektywę, gdy idzie o odpowiedź na pytanie Quid Juris?" [Ak. 252]

Majmon nie otworzył tu jednak, niestety, żadnej nowej perspektywy. W filozofii Kanta funkcjonuje pojęcie odpowiadające mniej więcej temu, co po- 
wyżej nazywano „materialna totalność idei intelektu”. Jest to demonstracja ${ }^{8}$, czyli modelowe wyobrażenie jakiegoś przedmiotu, o którym intelekt może myśleć tak, jak gdyby był intelektem intuitywnym. Sądy o takim przedmiocie mogą uzyskiwać tylko jedną z dwu form: albo, że coś jest konieczne, albo, że jest niemożliwe. Już od starożytności wiedziano, że najlepszym przykładem takich demonstracji, czy jak chce Majmon, „idei intelektualnych” są przedmioty geometrii. Ale taki sam charakter mogą mieć przecież idealne, wyobrażone dla potrzeb teorii przedmioty nauk przyrodniczych.

O ile jednak uznamy, że właściwymi przedmiotami poznania w ogóle są owe idee intelektu, natychmiast natrafiamy na stary problem: jak uzyskać zgodność tych idei z fenomenami zmysłu zewnętrznego albo choćby, jak połączyć jedne i drugie w jednolitą całość? Całość ta musiałaby przecież mieć nie tylko formalny wymiar, jak u Kanta, ale i materialny. To zaś kłóci się z podstawowymi założeniami filozofii krytycznej, Kant wyjaśnia więc Majmonowi za pośrednictwem Herza:

Nie możemy też wytłumaczyć, dlaczego przy formowaniu możliwego poznania jedna forma zgadza się $\mathrm{z}$ inną, bo musielibyśmy $\mathrm{w}$ tym celu posiadać inny ogląd niż ten, który jest nam właściwy oraz inny intelekt, z którym moglibyśmy postrzegać rzeczy same w sobie. Wszelki intelekt możemy oceniać tylko z pozycji naszego intelektu. Wszelkie zaś formy oglądu tylko z pozycji naszych form oglądu [Ak. 262].

Majmon nie przejął się zupełnie tym wyjaśnieniem. W liście do Kanta z 20 września 1791 roku [Ak. 486] pisał zdecydowanie: „Ogląd moim zdaniem nie jest zwrócony na nic innego oprócz siebie”. I dalej czytamy: „To, że każdy ogląd sprowadza się do jakiegoś substratum jest złudzeniem transcendentalnej władzy czynienia przedstawień”.

Zasadniczą kwestię różnicy pomiędzy przedmiotami zmysłu zewnętrznego i wewnętrznego postrzegał więc Majmon następująco: Prawdziwymi przedmiotami poznania są owe idee intelektu, myśląc o których, intelekt staje się intuitywny, bo równocześnie je ogląda. Materialna jedność procesu poznania równa się formalnej. Oczywiście istnieją też inne przedmioty poznania, takie jak idee niezgodne $\mathrm{z}$ prawami intelektu, czy wreszcie fenomeny jako tak zwane przedmioty zmysłu zewnętrznego. Jedne i drugie nigdy do końca nie zgadzają się z prawami intelektu. Wynika to stąd, że są ,złu-

\footnotetext{
${ }^{8}$ Por. I. Kant, Krytyka czystego rozumu, A 734.
} 
dzeniem transcendentnej władzy czynienia przedstawień". Transcendentne użycie rozumu jest zaś użyciem pozornym. Tu oznacza ono przekonanie, że poza granicą wyobraźni jako empiryczne przedmioty same w sobie istnieją tak zwane przedmioty zmysłu zewnętrznego.

Jedność świata jest więc jednością dokonującą się mocą podpadania pod prawa intelektu. Coś, co pod te prawa nie podpada, jest złudzeniem, tym mniej rzeczywistym, im bardziej oddziela się od tajemniczych idei intelektu. Tak pojmowana jedność świata osiągnięta przez jedność procesu poznania jest jednością zarówno materialną, jak i formalną. Kant był w stanie osiągnąć tylko tę ostatnią.

Tak sformułowane stanowisko Majmona nie było w historii filozofii czymś nowym. Kant, oddzielając dwa źródła procesu poznania, receptywność i samorzutność, przekroczył płaszczyznę sporu racjonalizmu i empiryzmu. Majmon wraca ku racjonalizmowi. Uważa, że mocą samego tylko intelektu można orzekać, czy coś istnieje, czy nie. Naprawdę istnieje więc dla niego tylko świat idei intelektu, bo te podpadają ściśle pod prawa intelektu. Natomiast przywołane przeze mnie wcześniej jako przykład pióro, którym oto piszę, jako fenomen zmysłu zewnętrznego byłoby dla Majmona złudzeniem, gdyż jego istnienie „oto teraz” jest nielogiczne. Przekonanie o istnieniu tak zwanego świata zewnętrznego stanowi wynik błędu, który powstał po transcendentalnym, czyli niewłaściwym użyciu władzy czynienia przedstawień.

Jedność systemu apercepcji w interpretacji Majmona nie uwzględnia więc w ogóle tak ważnej dla Kanta kategorii aprehensji, jako możliwości syntezy zmysłowej części poznania wyłącznie siłą czystych form oglądu. To prawda, że problem wzajemnej relacji pojęć apercepcji i aprehensji sam w sobie jest w filozofii Kanta niejasny. Toczą się spory, czy coś takiego jak czysta aprehensja jest w ogóle możliwe. Odpowiedź na te wątpliwości dotyczy już jednak psychologii, bo sprowadza się do kwestii: czy będąc człowiekiem, można tylko postrzegać i wyobrażać sobie, nie myśląc w kategoriach.

Niezależnie jednak od wszystkiego rozróżnienie dwu autonomicznych źródeł poznania: receptywności i spontaniczności odgrywało w filozofii Kanta czołową rolę. Tej oczywistej prawdy broni wyimaginowany Kant (co prawda w sposób niezgodny z poglądami prawdziwego Kanta) we wspomnianym dialogu Majmona. Rozmowa między Kantem $i$ jednym $z$ jego uczniów. Kant został tu przedstawiony jako naiwny empirysta, który na pytanie rozmówcy: 
„Wynika stąd, że intelekt ma tylko to, co może być dane przez wrażenia", odpowiada:

„Rozwój intelektu dokonuje się oczywiście przez wrażenia; ale gdy jest on już raz rozwinięty, to z pewnością może pójść dalej niż go prowadzą wrażenia".

Oczywiście taka wektorowa, jednoprzyczynowa zależność intelektu od wrażeń byłaby dla prawdziwego Kanta nonsensem. Władze poznawcze składają się dla niego z dwóch pni: ze zmysłów i z intelektu (dalej rozumu). Rozważania, co w rozwoju poznania następuje jako pierwsze, a co jako drugie są nonsensowne już choćby dlatego, że sama chronologia czasowa jest częścią formalnej możliwości władz czystego rozumu. Stanowisko głoszone tu przez Kanta musiałby więc reprezentować ktoś, kto obserwuje proces poznawczy spoza procesu poznawczego. Tego jednak Kant $\mathrm{z}$ dialogu Majmona nie może wiedzieć, bo czas i przestrzeń uznaje on nie za formy oglądu, lecz za formy, które intelekt wyciąga z doświadczenia. Mówi:

„Tak na przykład intelekt zdradza, czym jest przestrzeń, aczkolwiek przestrzeń nie wywiera na nas żadnych wrażeń”.

Trudno o bardziej bezsensowne stanowisko. Wynikałoby z niego na przykład, że organizm, który właśnie oto w ogóle nie myśli pojęciami, nie jest w stanie uskoczyć przed zagrożeniem, dopóki nie wymyśli sobie, czym jest przestrzeń, w którą ma uskoczyć.

Tu rozmówca N. stawia pytanie: a czym jest owa przestrzeń, w której zawarte są wszystkie rzeczy? Nie może być ona rzeczą, nie może więc być nam dana przez doświadczenie. Czytamy:

„...przestrzeń jest rzeczywistym czymś - głosi N. - pozostaje jednak niepojęte, jak czymś rzeczywistym może być coś, co nie może być przedmiotem".

Przyciskany Kant, odpowiadając, brnie dalej w niedorzeczności. Jego rozmówca pyta:

N. „Przez co przedmiot wywiera na nas wrażenia?”

K. „Przez tworzywo”.

N. „Czym jest to, co Pan zwie tworzywem?”

K. „Materialną zawartością przedmiotu”.

N. „Przedmiot jest zatem przedstawionym w przestrzeni tworzywem?”

K. „Tego nie wiem i nie mogę wiedzieć, bo jest dla człowieka niemożliwe poznać coś poza przestrzenią".

${ }^{9}$ Wszystkie cytaty z tego dialogu odnoszą się do opublikowanego w niniejszym tomie przekładu. 
Kant twierdzi więc rzekomo, co następuje. Podstawą rzeczy zewnętrznych jest ich tworzywo, czyli materia. Na tę materię człowiek nakłada formę przestrzenności i powstają przedmioty zmysłu zewnętrznego. Ale czym jest owa materia poza przestrzenią i skąd wiadomo, że w ogóle ona jest filozof nie wie i nie chce wiedzieć. Stwierdza po prostu:

„Tworzywo jest co prawda nieznane, ale nie nieuświadomione, wiemy bowiem, bezspornie, że ono jest i że wytwarza treść przedmiotu”.

Tu rozmówca zadaje pytanie, jak się mówi w języku potocznym „wzięte z Księżyca”.

N. „Czy nie może istnieć istota, w której nie zawiera się przedstawienia przestrzeni i dla której byłoby możliwe postrzeganie samego tworzywa, a nie przedmiotu?"

Kant nie odpowiada, jak można by tego od niego oczekiwać, że nie jest w stanie używać modalnej kategorii możliwości do rzeczy, co do których w ogóle nie wiadomo, jak ich doświadczyć. Mówi tylko:

„Bardzo możliwe”.

Dialog kończy się dość nieoczekiwanie. Przyciśnięty do muru Kant mówi: „...najpierw musi Pan tak przyswoić sobie mój język, że żadnemu słowu nie nada Pan innego sensu niż ten, który ja mu nadaję".

Innymi słowami: Kant stwierdza, że jeśli Majmon będzie wszystkie słowa prowadzonego dialogu rozumiał tak, jak on sam, to będzie również w pełni akceptował jego filozofię. Majmon nie wyraża jednak na to zgody i chce rozszerzyć filozofię Kanta tak, by powstał z niej racjonalistyczny idealizm.

Problem polega jednak na tym, że sam „Kant”, bohater omawianego dialogu, jak zaznaczyliśmy, nie bardzo prezentuje tu poglądy prawdziwego Kanta. Za podstawę istnienia zjawisk zmysłu zewnętrznego uznaje tajemniczą materię, o której nic nie wiadomo, oprócz tego, że jest nieprzestrzenna. W tym duchu tworzono, oczywiście, metafizyczne interpretacje filozofii Kanta. Ich zwolennicy zakładali, że rzecz sama w sobie to nieznane coś, co musi istnieć i co pobudza zmysły tak, że powstaje zjawisko.

Interpretacja taka nie zgadza się z literą filozofii Kanta. Pytanie o rzecz samą w sobie ma w niej sens logiczny, a nie metafizyczny, gdyż domniemana odpowiedź na nie już z założenia nie odnosi się do strony empirycznej. Kant ostatecznie stwierdza tylko: można, a nawet trzeba (mocą konieczności transcendentalnej) postawić pytanie o rzecz samą w sobie. Lecz nie wiadomo ani jak na nie odpowiadać, ani nawet gdzie je skierować. Z konieczności pytania nie wynika zaś jeszcze konieczność istnienia jego obiektu, zwłaszcza $\mathrm{w}$ transcendentalnym użyciu rozumu. 
Majmon próbuje wykazać istnienie wszelkich przedmiotów zmysłowych, odwołując się do syntezy pojęciowej. Wyznaje zasadę, że rzeczywistość to nie tylko ogół poznawanych faktów, lecz także łączących te fakty związków. Odkrywa więc poniekąd tezę Hegla: „co jest rzeczywiste jest rozumne, a co jest rozumne jest rzeczywiste”. To, czego doświadczamy, a co nie da się wytłumaczyć przez logiczny związek z wszystkimi innymi faktami jest tylko empirycznym pozorem. Jest więc nierzeczywiste.

Kant oczywiście nigdy nie zgodziłby się z taką tezą. Inaczej też rozumie on pojęcie rozumu. Za fakty niewątpliwie rzeczywiste, a niedające się wyjaśnić na mocy sądów determinującej władzy sądzenia uzna na przykład doświadczenia podlegające refleksyjnej władzy sądzenia, zwłaszcza piękna i życia.

Natomiast fakt, że należy odróżnić postrzeganie świata zewnętrznego i wyobrażanie sobie świata wewnętrznego jest dla niego tak samo oczywisty, jak dla każdego innego, nawet prostego człowieka. Postrzegamy te światy jako różne i mamy ich dwa różne pojęcia. Formalną jedność obu światów ustanawia pierwotnie przestrzeń jako czysta forma oglądu. Natomiast to logiczne ustalenie ich granicy jest już niemożliwe.

Koncepcję Majmona łatwo można poznać $\mathrm{z}$ edycji jego głównego dzieła Versuch über Transcendentalphilosophie. W niniejszym artykule chciałem przedstawić tę koncepcję, odwołując się do materiałów bardziej osobistych. Dzięki temu możemy się dowiedzieć, jaki był bezpośredni stosunek Majmona do Kanta oraz co Kant myślał o koncepcji Majmona.

Odrzucił ją dokładnie z tego samego powodu, z jakiego odrzucił wielokrotnie koncepcję Fichtego. Stwierdza: z samej logiki nie da się wyprowadzić żadnego istnienia przedmiotów, tu potrzebna jest metafizyka. Idealizm niemiecki, kroczący drogą od Fichtego do Hegla, nie zaakceptuje tego ograniczenia. Jego zwolennicy uznają prymat logiki nad estetyką transcendentalną i odrzucą przedmioty zmysłu zewnętrznego rozumiane tak, jak rozumiał je Kant.

Majmon, gdy idzie o głoszenie takiego stanowiska, wyprzedził o kilka lat Fichtego, który się na niego powoływał ${ }^{10}$. Być może stanowił więc na drodze od Kanta do klasycznego idealizmu niemieckiego o wiele ważniejsze ogniwo niż się zazwyczaj przyjmuje.

${ }^{10}$ Por. J. G. Fichte, Teoria wiedzy, przeł. M. J. Siemek, Warszawa 1996, s. 3, 47-48, 66, 94, 97, $121,244,434-436,494$. 


\title{
Bibliografia
}

Aleksandrov G. F., Historia filozofii, t. 3, przel. S. Macheta, Warszawa 1972.

Fichte J. G., Teoria wiedzy, przeł. M. J. Siemek, Warszawa 1996.

Kant I., Krytyka czystego rozumu, przeł. M. Żelazny, [w:] I. Kant, Dzieła zebrane, t. 2, Toruń 2013.

Kant I., O zmyśle wewnętrznym, [w:] tenże, O postępach metafizyki, przeł. A. Banaszkiewicz, Gdańsk 2007.

[Majmon S.], Gespräch zwischen Kant und einem seiner Zuhörer.

[Majmon S.], Gedanken über bürgerliche Verbesserung der Hebraiker.

Majmon S., Philosophisches Wörterbuch, Berlin 1791.

\begin{abstract}
Salomon Maimon's Attitude towards the Philosophy of Kant (in the Light of Their Correspondence and a Recently Discovered Manuscript of A Dialogue Between Kant and One of His Students)
\end{abstract}

The article familiarizes us with Salomon Maimon (1754-1800), a self-taught philosopher of Jewish descent, and with his attitude to the scientific views of Immanuel Kant. Although Maimon depicted himself as a follower of Kant, the reality contradicts this picture. The conclusions drawn in the article are based on Maimon's letters and his manuscript of A Dialogue between Kant and One of His Students discovered only recently.

The abovementioned correspondence with Kant clearly shows Maimon's position in relation to the views of the philosopher from Königsberg. The letters, most of which remained unanswered, are written in a characteristic, somewhat audacious manner. Maimon begins them with glorifying Kant's philosophy but then suggests numerous corrections concerning not only its insignificant details but also some principal issues which would radically change the whole system of Kant's philosophy. Presumably that justifies the fact that Maimon received but one answer in the whole correspondence. Kant answered it at the instigation of his friend, Marcus Herz, with whom Maimon won favour. Later, however, Kant bore a grudge against Herzto such an extent that their own correspondence, previously frequent and very personal in character, almost ceased, becoming scarce and official.

This, however, did not discourage Maimon, who in his Autobiography (1792) claimed that Kant had a high regard of him. The Jewish self-taught philosopher 
kept writing letters to Kant, and as he could not bear the lack of any answer, he decided to respond to the lettershimself. Kant's would-be answers are contained in the abovementioned manuscript of A Dialogue between Kant and One of His Students, which for Maimon was a kind of compensation for Kant's repudiation. Thetitle dialogue is between the Königsberg philosopher and a student $\mathrm{N}$, whose views are identical with those of Maimon. It is hard to overlook the importunity of his attacks on Kant, whose answers are far more polite perhaps due to the fact he cannot equal him. In the dialogue, Kant contradicts himself, is lost in the arguments, and finally agrees with the statements of $\mathrm{N}$ despite the fact that they are quite distant from his own critical philosophy.

$\mathrm{N}$ - that is Maimon - casts doubts concerning various aspects of Kant's philosophy, e.g. the notion of space as a form of pure intuition, and Kant's attempts to defend his position are quite helpless. Frequent statements such as "I do not know" or "highly probable" compound Maimon's picture of Kant. It turns out, however, that in some of the theses contained in the dialogue Maimon was close the views of Fichte, which Kant refused as well. Perhaps, then, Maimon was a link between Kantian philosophy and the classical German idealism, a link much more important than it is generally acknowledged.

Key words: Immanuel Kant, Salomon Maimon 